\title{
Research on China's OFDI Location Strategy in EU from the Perspective of Host Country Manufacturing Industry GVC Evolution
}

\author{
Pei Yu, Qiaoqiao Chen \\ School of Economics, Wuhan University of Technology, Wuhan, China \\ Email: peguyvincent@hotmail.com,1157123145@qq.com
}

How to cite this paper: Yu, P., \& Chen, Q. Q. (2020). Research on China's OFDI Location Strategy in EU from the Perspective of Host Country Manufacturing Industry GVC Evolution. American Journal of Industrial and Business Management, 10, 315-326. https://doi.org/10.4236/ajibm.2020.102020

Received: January 20, 2020

Accepted: February 10, 2020

Published: February 13, 2020

Copyright $\odot 2020$ by author(s) and Scientific Research Publishing Inc. This work is licensed under the Creative Commons Attribution International License (CC BY 4.0). http://creativecommons.org/licenses/by/4.0/

\begin{abstract}
Based on the driven mode and the form of labor division, the two paths that affect the evolution of the host country's manufacturing industry GVC, this paper constructs a mechanism on their impacts on China's OFDI location strategy, and then verifies the theoretical hypotheses by taking China's OFDI stock across $26 \mathrm{EU}$ member states and 13 manufacturing sub-industries during 2003 to 2014 as the sample. The empirical results obtained by comprehensive Generalized Least Squares (GLS) estimation show that, from the perspective of the GVC driven model, the high-tech level, rich human capital under the producer-driven model, and huge market potential based on buyer-driven mode are important factors affecting China's OFDI location choice across EU member states. From the perspective of GVC labor division, the higher vertical specialization and host country's GVC status of manufacturing sub-industry attract the inflow of Chinese investments.
\end{abstract}

\section{Keywords}

GVC Evolution, China's OFDI, Location Strategy, EU, Manufacturing Industry

\section{Introduction}

With the deepening of the globalization of production, the international labor division based on the Global Value Chain (GVC) has become the main form for enterprises from various countries to participate in international competition. According to statistics from the United Nations Conference on Trade and Development (UNCTAD, 2013), GVC dominated by multinational enterprises (MNEs) accounts for $80 \%$ of international trade, and MNEs' main business ac- 
tivities across the world are still carried out in the form of international direct investment. Therefore, the trend of cross-border capital flows led by MNEs and the evolution of GVC complement each other.

Since 2004, EU has become China's largest trading partner for more than ten years, and meanwhile, China's Outward Foreign Direct Investment (OFDI) in EU has been increasing rapidly. In terms of investment scale, according to China's Foreign Direct Investment Statistics Bulletin, from 2005 to 2017, China's OFDI stock and flow in EU has been increased from 768 million US dollars to 86.015 billion dollars, and from 189 million US dollars to 10.267 billion dollars respectively. Meanwhile, regard to industry distribution, China's OFDI in EU manufacturing industry increased the most significantly and achieved 40-fold growth from 2007 to 2017. In terms of geographical distribution, the investments of Chinese manufacturing enterprises in EU are mainly distributed in Germany, the UK, France, the Netherlands and Sweden.

Compared with China, EU countries have earlier industrialization process, high technology intensity and more mature market mechanism, and therefore, high GVC status and stronger control capabilities. Especially after the eastward expansion, the length of GVC within EU has been further extended, and the location of manufacturing sector based on its dynamics comparative advantage has been changed (Gao \& Zheng, 2018). In the context of the rapid growth of China's OFDI in EU manufacturing industries, an in-depth analysis on the impact on Chinese OFDI location strategy, brought about by EU manufacturing sector's GVC evolution, are significant. It can assist Chinese MNEs to better understand the comparative advantages of EU manufacturing industry, and combine with its own characteristics to formulate a reasonable diversified investment strategy, and to promote and consolidate furtherly the comprehensive strategic partnership between China and EU by enhancing the international competitiveness of Chinese MENs.

However, the previous relevant studies mainly discussed and tested the influencing factors on China's OFDI location strategy from the traditional international investment theories (Chen et al., 2019; Liu \& Wang, 2016; Zhu \& Ren, 2018; Clegg \& Voss, 2016), and there are few researches based on GVC perspectives. Thus, this paper innovatively analyzes location determinants of Chinese OFDI across EU member states from the perspective of driven mode and labor division, which are the main two paths of GVC evolution in host country, and especially considers different characteristics of manufacturing sub-industries.

\section{Theoretical Analysis and Hypotheses}

The evolution of GVC can be understood as the changing process of comparative advantages of different countries under the background of deepening international labor division. The driven mode and labor division form of GVC represent two paths of GVC evolution. The "Dual-Driven" theory of Global Commodity Chain (GCC) has been first proposed in 1994 (Gereffi \& Korzeniewicz, 1994), and then has been explored by one scholar, who defined the producer driven mode as that producers are located in the high-end $\mathrm{R} \& \mathrm{D}$ and production manu- 
facturing links of GVC by virtue of their monopoly advantages such as technology and human capital, and buyer driven mode as investors or owners with brands and domestic marketing networks can stimulate huge market demand and form a very large market potential (Henderson, 1998).

Regarding the form of GVC labor division, the concept of vertical specialization has been first proposed in 1976 (Balassa, 1976), namely, in the global labor division, the continuous production of a kind of goods is divided into a vertical trade chain, and each country gives value to each stage of the production process by virtue of its comparative advantage. With the increasingly refined and fragmented division of production, the production structure has became more and more complex. Due to the fragmentation of production stages of a product in different countries, the intermediate inputs cross the national borders many times. Thus, GVC labor division (Production Non-Integration) characterized by international production division has become the main bearing form of globalization in the world (Feenstra \& Robert, 1998).

Based on this, this paper constructs the mechanism on impacts on China's OFDI location strategy, brought about by two paths of host country GVC evolution in EU manufacturing sub-industry, and then proposes hypotheses that need to be tested.

\subsection{The Impacts of EU Manufacturing Sector's GVC Driving Model on China's OFDI Location Strategy}

\section{1) Producer-driven and China's OFDI location strategy}

With the continuous deepening of the international division of labor system and the continuous transfer of manufacturing links, the competitive advantages of developed countries are increasingly reflected in intangible assets. For Chinese enterprises, only by acquiring technology and controlling the core links can they have the chance to become the "chain master" of the GVC. It has become a realistic choice for many Chinese MNEs to actively acquire intangible assets in developed countries with rich technology and human capital elements by means of OFDI (Pei \& Zheng, 2011). EU countries have the traditional international competitiveness in automobile, aviation and other industries, which belong to the typical GVC producer driven mode. Chinese MENs "south-north" flow of OFDI, can learn and absorb their advanced technology through the host country's "technology and knowledge invest spillover effect". By conducing "Going out" strategies, Chinese MENs can master the core technology methods and advanced management experience through their overseas subsidiaries, and through the internal transactions and other "feed back" channel, and as a result, can improve the overall technical level of the industry by "demonstration effect" and "ripple effect", and then furtherly improve the parent company's ability to integrate global advantageous resources. Thus, this paper proposes the following assumptions:

Hypothesis 1: If GVC of a manufacturing industry in an EU member state is producer driven, it can attract more Chinese OFDI with strategic assets-seeking motive. 


\section{2) Buyer-driven model and China's OFDI Location Strategy}

Traditional labor-intensive industries such as textile in EU countries belong to GVC buyer driven mode, which highly depends on brand strength and global market sales network. Enterprises in member states can generate spatial spillover effect of market demand within EU, which provides huge market potential for China's OFDI. There is still a big gap between the brand value of Chinese enterprises and that of European ones. In addition, due to the squeeze effects of foreign well-known brands in China's domestic market, the living space of Chinese enterprises are threatened. In order to improve the global market share, more and more Chinese MNEs have been entered EU in the form of OFDI. Therefore, this paper proposes the following assumption:

Hypothesis 2: If GVC of a manufacturing industry in an EU member states is driven by buyers, it will be more favored by China's OFDI location strategy.

\subsection{The Impacts of EU Manufacturing Sector's GVC Division on China's OFDI Location Strategy}

\section{1) Vertical specialization division and China's OFDI location strategy}

A country's total exports can be divided into 16 parts based on the WWZ method, and according to sources and final absorption of the export products' value added, Wang et al. explained the meaning of the level of forward vertical specialization and then pointed out that if the proportion of foreign added value of a country's intermediate exports to the total exports is larger, especially for more and more intermediate exports to a third country and used in the production of final products, which will reveal that this country is facing industrial upgrading (Wang et al., 2015). Thus, the higher the level of forward vertical specialization division of manufacturing industry in EU countries, which means the richer factor endowment and the gradual improvement of industrial supporting facilities, the more China's OFDI will be attracted ,aiming at integrating and utilizing global resources and then enhancing their international competitiveness. Therefore, this paper proposes the following assumption:

Hypothesis 3: The higher the level of forward vertical specialization of a manufacturing sub-industry in an EU member state, the more China's OFDI will enter.

2) Production non-integration of labor division and China's OFDI location strategy

Because of the non-integration of production, each country's position of GVC labor division are determined by its competitive advantage. According to the "Smile curve", the closer a country's labor division position approaches to the two high-ends of the U-shaped curve (such as R\&D, brand and other links), the higher the added value can be created by that country; otherwise, if a country is located in the middle of the U-shaped curve (such as parts, assembly and other links), lower added value will be realized. Taking EU manufacturing sector as an example, high position of GVC labor division means richness of high-quality resources, and therefore, Chinese MNEs can make more efficient use of and in- 
tegrate global advantage resources through OFDI. The following assumption is proposed:

Hypothesis 4: The higher the level of production non-integrated division of labor (GVC status) of a manufacturing sub-industry in an EU member state, the more China's OFDI will enter.

Based on the above assumptions, this paper constructs a mechanism chart, as shown in Figure 1. Besides, the research hypothesis will be empirically tested by comprehensive GLS in the next section.

\section{Empirical Method and Test}

\subsection{Regression Model Settings}

Based on the above theoretical analysis, this paper sets models (1) to (5) to test the hypothesis.

$$
\begin{aligned}
& \ln \text { ofdi }_{i r t}=\alpha_{0}+\alpha_{1} \ln \text { tech }_{i t}+\alpha_{2} \ln h_{u m}+\varpi_{1} X_{i t}+\varepsilon_{i}+\varphi_{t}+\gamma_{i t} \\
& \ln o f d i_{i r t}=\beta_{0}+\beta_{1} \ln m p_{i t}+\varpi_{2} X_{i t}+\varepsilon_{i}+\phi_{t}+\gamma_{i t} \\
& \ln o f d i_{i r t}=\theta_{0}+\theta_{1} v s_{i r t}+\varpi_{3} X_{i t}+\varepsilon_{i}+\phi_{t}+\gamma_{i t} \\
& \ln o f d i_{i r t}=\eta_{0}+\eta_{1} g v o_{i r t}+\varpi_{4} X_{i t}+\varepsilon_{i}+\phi_{t}+\gamma_{i t} \\
& \ln o f d i_{i r t}=\varphi_{0}+\varphi_{1} \ln \text { tech }_{i t}+\varphi_{2} \ln h u m_{i t}+\varphi_{3} \ln m p_{i t}+\varphi_{4} \ln v s_{i r t} \\
& +\varphi_{5} \ln g v o_{i r t}+\varpi_{5} X_{i t}+\varepsilon_{i}+\phi_{t}+\gamma_{i t}
\end{aligned}
$$

In the model (1) to (5), ofdi $i_{i r t}$ represents China's investment stock in manufacturing industry sector $\mathrm{r}$ of host country $i$ in year $t$, tech $_{i t}$, hum $m_{i t}$ and $m p_{i t}$ represent technology level, human capital and market potential of host country $i$ in year $t$ respectively; $v s_{i r t}$ and $g v o_{i r t}$ represent vertical specialization level and GVC status of manufacturing sector $r$ in host country $i$ in year $t ; X_{i t}$ represents control variables, including labor cost, open level of foreign investment, infra level of host country and institutional distance between China and EU countries; $\alpha, \beta, \theta, \eta, \phi$ and $\varpi$ are parameters to be evaluated; $\varepsilon_{\mathrm{i}}$ is individual effect; $\phi_{t}$ is time effect; $\gamma_{i t}$ is random term. In order to reduce

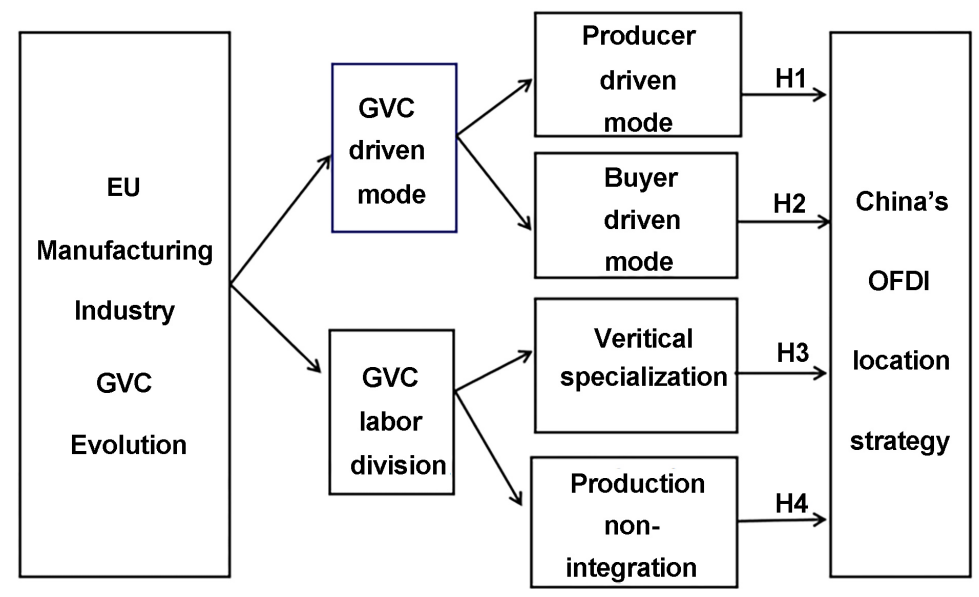

Figure 1. Mechanism diagram of the impact of GVC evolution in EU manufacturing industry on China's OFDI location strategy. 
the heteroscedasticity effects, Each variable is logarithmically processed. Since ofdi $i_{\text {irt }}$ is zero in individual years and countries, based on previous method of relevant scholars (Ji et al., 2018), this paper takes logarithm after ofdi $i_{\text {irt }}+0.0001$, and some data of $v s_{i r t}$ and $g v o_{i r t}$ are negative, we adds $v s_{i r t}$ and $g v o_{i r t}$ to 1 respectively (Li, 2015), and then takes logarithm.

\subsection{Variable Description}

1) ofdi . China's OFDI stock in the manufacturing sector of EU countries. The statistical bulletin of China's outward foreign direct investment issued by the National Bureau of statistics, including the stock and flow data of China's OFDI in EU countries. Due to the serious lack of information on China's OFDI flows to Estonia and Slovenia, this research only takes $26 \mathrm{EU}$ member states as sample. However, there is also a lack of data on China's OFDI across EU countries. For overcoming this barrier, this paper combines the relevant information of the directory of overseas investment enterprises (Institutions) issued by the Ministry of Commerce of the People's Republic of China to calculate ofdi (Liu \& Mao, 2016). Assuming that the capital stock of OFDI of manufacturing sector $r$ of China to EU host country $i$ in period $t$ is $K_{\text {irt }}$, and the total China's OFDI flow to EU host country $i$ is Flow $_{i r}, S_{i t}$ and $S_{i r t}$ respectively represent the number of newly established subsidiaries of Chinese enterprises in all industries and manufacturing sector $\mathrm{r}$ of EU host country $i$ in period $t$, it can be calculated according to the relevant domestic investors in the directory of overseas investment enterprises (Institutions) issued by the Ministry of Commerce of the People's Republic of China. For example, in the first phase, China's OFDI capital stock of manufacturing sector $r$ of EU host country $i$ is $K_{i r 1}=\left(\frac{S_{i r 1}}{S_{i 1}}\right) \times K_{i 1}$, where $S_{i 1}$ and $S_{i r 1}$ represent the number of new subsidiaries of Chinese enterprises in all industries and manufacturing sector $\mathrm{r}$ of EU host country $i$ in the first phase, and $K_{i r 1}$ is the OFDI stock of manufacturing sector $r$ of EU host country $i$ in the first phase. When $t>1$, China's investment stock in manufacturing sector $r$ of EU host country $i$ in period $t$ is: $K_{i r t}=\max \left[0, K_{i r t-1}+\left(\frac{S_{i r t}}{S_{i t}}\right) \times\right.$ Flow $\left._{i t}\right]$. As may Flow $_{i t}$ be a negative value, the maximum value of zero and $K_{\text {irt }}$ is taken. Meanwhile, for $S_{i t}$, some years and countries are zero, this paper will divide them into all industries. Moreover, in this paper, six manufacturing sub-industries are merged by two sub-industries based on in Word Input-Output Database (WIOD).

2) Producer driven mode. Under the GVC producer driven mode, the host country posses the advantages of key technologies and production capacity. Thus, this paper uses the host country's technology level (tech) and human capital (hum) as proxy variables, the proportion of R\&D expenditure in GDP and higher education labor force in host country are used to measure them respectively. 
3) Buyer driven mode. In GVC buyer driven mode, the host country has brand advantage and strong market scale. In addition, as an regional economic organization, EU countries have the third country market potential formed by brand effect and market scale, that is, the market demand of each country produces spatial spillover effect, which provides potential market demand for China OFDI. In this paper, the market potential $(m p)$ is used as the agent variable of the buyer driven model, and this paper calculate it based on previous method (Ma \& Liu, 2016), $m p_{i t}=\sum_{j \neq i} \frac{1}{d_{i j}} G D P_{j t}$, where $m p_{i t}$ is the market potential of host country $i$ in year $t, d_{i j}$ is the geographical distance between host country $i$ and host country $j$, and $G D P_{j t}$ is the GDP of host country $j$ in year $t$.

4) Vertical specialization. According to the definition of forward vertical specialization, this paper measures the degree of vertical specialization $\left(v s_{i r}\right)$ by using the ratio of the foreign added value $\left(F V A_{-} I N T_{i r}\right)$ of the intermediate products exported by the manufacturing sector $r$ of the host country to its total exports $\left(E_{i r}\right)$, which can reflect the industrial upgrading trend of the manufacturing sector in the host country.

5) Production non integration. GVC status reflects the real strength of a certain industry in the production non integration (Huang et al., 2018). This paper uses the GVC status of the manufacturing sub-industry in the host country as the proxy index of production non integration (Koopman et al., 2010), that is $g v o_{i r}=\ln \left(1+\frac{D V A_{-} I N T_{-} R E X_{i r}}{E_{i r}}\right)-\ln \left(1+\frac{F V A_{i r}}{E_{i r}}\right)$, where $D V A_{-} I N T_{-} R E X_{i r}$ represents the domestic indirect added value of manufacturing sub-industry $r$ in host country $i, F V A_{i r}$ represents the foreign added value of manufacturing sub-industry $\mathrm{r}$ in host country $i, E_{i r}$ represents the total export of manufacturing sector $r$ of host country $i$.

6) Control variables. This paper selects four control variables: labor cost (cost), infrastructure (infra), openness of foreign investment (open) and institutional distance (id) between home country and host country. Among them, the first three variables are measured by the GDP per capital of the host country, the number of broadband Internet users per hundred people and the proportion of foreign FDI stock in GDP respectively. For id, we select six indicators (discourse power and responsibility, political stability, government efficiency, rule of law and corruption control) to measure the system quality, obtains the comprehensive system quality indicators of a country through principal component analysis, and calculates it: id $d_{c i t}=\left|I_{i t}-I_{c t}\right| /\left|I_{c t}\right|$, where id $d_{c i t}$ represents the system distance between China $c$ and host country $i$ in year $t, I_{c t}, I_{i t}$ respectively represents the comprehensive system quality indicators of China $c$ and host country $i$ in year $t$.

\subsection{Data Source}

The data of this paper mainly comes from the World Bank Database, WIOD, 
UNCTAD Database and CEPII Database. For WIOD, the latest statistical data of it has been updated in October 2016. It contains the basic data of 56 industrial sectors of 44 economies from 2000 to 2014. And China's Foreign Direct Investment Statistics Bulletin has begun to count China's OFDI since 2003, thus, the sample in this paper covers the period from 2003 to 2014. Besides, the 56 industries are classified and counted according to ISIC Rev. 4. Based on this, the manufacturing industry of EU countries is divided into 13 sub sectors (C3: Manufacture of food products, beverages and tobacco products; C4: Manufacture of textiles, wearing apparel and leather products; C5: Manufacture of wood and of products of wood and cork; C6: Manufacture of paper and paper products, printing and reproduction of recorded media; C7: Manufacture of coke and refined petroleum products; $\mathrm{C} 8$ : Manufacture of chemicals and chemical products, manufacture of basic pharmaceutical products and pharmaceutical preparations; C9: Manufacture of rubber and plastic products; C10: Manufacture of other non-metallic mineral products; C11: Manufacture of basic metals, manufacture of fabricated metal products; C12: Manufacture of machinery and equipment n.e.c.; C13: Manufacture of computer, electronic and optical products, manufacture of electrical equipment; C14: Manufacture of motor vehicles, trailers and semi-trailers, Manufacture of other transport equipment; C15: Manufacture of furniture, waste collection, treatment and disposal activities, materials recovery, remediation activities and other waste management services).

\section{Empirical Results Analysis}

The comprehensive GLS estimation can overcome the problems of the disturbance term in econometric regression model, such as the problem of the heteroscedasticity between groups, the problem of the autocorrelation and the problem of the inter group simultaneous correlation (Huang et al., 2018), thus, this paper finally selects this method with the multiple fixed effects of time, industry and country to test the model.

Model (1) in Table 1 shows that, under the producer driven mode, the coefficients of technical level and human capital of EU countries are positive at the level of 5\%, Hypothesis 1 is confirmed. The level of high-technology and abundance of human capital in EU countries are an important location factor for attracting China's OFDI. And specially, the magnitude of human capital's coefficient is larger. This finding is consistent with Marshall's main path of positive agglomeration effect inside a localized industry. When the host country gathers a large number of professional talents, it can generate technology spillover effect through the "Human Capital Pool", and at the same time, it can also provide labor supply for Chinese affiliates motivated by strategic asset seeking.

Model (2) shows that, under the buyer driven mode, the coefficient of market potential of EU countries is positive at the level of 1\%, Hypothesis 2 is confirmed. The huge market potential helps EU countries build sales network with their strong brands. Besides, the market demand of EU countries can generate spatial spillover effect, it can supply for Chinese affiliates motivated by marketing seeking. 
Table 1. Regression results of manufacturing industry.

\begin{tabular}{|c|c|c|c|c|c|}
\hline \multirow{2}{*}{ Variables } & $\begin{array}{l}\text { Model } \\
\text { (1) }\end{array}$ & $\begin{array}{l}\text { Model } \\
(2)\end{array}$ & $\begin{array}{l}\text { Model } \\
\text { (3) }\end{array}$ & $\begin{array}{l}\text { Model } \\
\text { (4) }\end{array}$ & $\begin{array}{l}\text { Model } \\
\text { (5) }\end{array}$ \\
\hline & $\begin{array}{c}\text { Producer driven } \\
\text { mode }\end{array}$ & $\begin{array}{c}\text { Buyer driven } \\
\text { mode }\end{array}$ & $\begin{array}{c}\text { Vertical } \\
\text { specialization }\end{array}$ & $\begin{array}{c}\text { Production } \\
\text { non-integration }\end{array}$ & GVC Evolution \\
\hline lntech & $\begin{array}{l}1.088^{* *} \\
(2.50)\end{array}$ & & & & $\begin{array}{c}1.229^{* *} \\
(2.39)\end{array}$ \\
\hline lnhum & $\begin{array}{c}1.137^{* *} \\
(2.76)\end{array}$ & & & & $\begin{array}{c}1.886^{* *} \\
(2.88)\end{array}$ \\
\hline $\operatorname{lnmp}$ & & $\begin{array}{c}1.720^{* * *} \\
(3.25)\end{array}$ & & & $\begin{array}{c}1.782^{* * *} \\
(3.57)\end{array}$ \\
\hline $\ln v s$ & & & $\begin{array}{l}0.177^{*} \\
(1.81)\end{array}$ & & $\begin{array}{l}0.365^{*} \\
(1.68)\end{array}$ \\
\hline lngvo & & & & $\begin{array}{c}0.717^{\star *} \\
(2.09)\end{array}$ & $\begin{array}{c}0.776^{* *} \\
(2.52)\end{array}$ \\
\hline $\operatorname{lncost}$ & $\begin{array}{c}-0.458^{* * *} \\
(-3.09)\end{array}$ & $\begin{array}{c}-0.534^{* *} \\
(-2.67)\end{array}$ & $\begin{array}{c}-3.770^{\star * *} \\
(-5.66)\end{array}$ & $\begin{array}{c}-3.814^{\star * *} \\
(-5.69)\end{array}$ & $\begin{array}{c}-2.932^{* *} \\
(-2.46)\end{array}$ \\
\hline lninfra & $\begin{array}{l}0.132 \\
(1.31)\end{array}$ & $\begin{array}{c}0.538^{\star * *} \\
(4.81)\end{array}$ & $\begin{array}{c}0.186^{*} \\
(1.73)\end{array}$ & $\begin{array}{l}0.180^{\star} \\
(1.67)\end{array}$ & $\begin{array}{c}0.198^{\star *} \\
(2.48)\end{array}$ \\
\hline lnopen & $\begin{array}{l}0.178^{* * *} \\
(4.09)\end{array}$ & $\begin{array}{l}0.162^{\star *} \\
(2.31)\end{array}$ & $\begin{array}{c}0.978^{* * *} \\
(6.34)\end{array}$ & $\begin{array}{c}0.967^{* * *} \\
(6.26)\end{array}$ & $\begin{array}{c}0.682^{* * *} \\
(6.68)\end{array}$ \\
\hline lnid & $\begin{array}{l}-0.065^{\star} \\
(-1.33)\end{array}$ & $\begin{array}{l}-0.063^{*} \\
(-1.53)\end{array}$ & $\begin{array}{l}-0.007^{\star} \\
(-1.76)\end{array}$ & $\begin{array}{l}-0.003^{*} \\
(-1.77)\end{array}$ & $\begin{array}{l}-0.108^{*} \\
(-1.94)\end{array}$ \\
\hline _Cons & $\begin{array}{l}6.608^{* *} \\
(2.48)\end{array}$ & $\begin{array}{c}-8.943^{* * *} \\
(-5.07)\end{array}$ & $\begin{array}{c}31.944^{* * *} \\
(4.59)\end{array}$ & $\begin{array}{c}32.313^{* * *} \\
(4.65)\end{array}$ & $\begin{array}{c}38.776^{* * *} \\
(5.67)\end{array}$ \\
\hline Industryfixed effect & yes & yes & yes & yes & yes \\
\hline Time fixed effect & yes & yes & yes & yes & yes \\
\hline Country fixed effect & yes & yes & yes & yes & yes \\
\hline Wald test & $\begin{array}{c}\text { Prob }>\text { chi }^{2} \\
=0.0000\end{array}$ & $\begin{array}{l}\text { Prob }>\text { chi }^{2} \\
=0.0000\end{array}$ & $\begin{array}{c}\text { Prob }>\text { chi }^{2} \\
=0.0000\end{array}$ & $\begin{array}{c}\text { Prob }>\text { chi }^{2} \\
=0.0000\end{array}$ & $\begin{array}{c}\text { Prob }>\text { chi }^{2} \\
=0.0000\end{array}$ \\
\hline Wooldridge test & $\begin{array}{l}\text { Prob }>\text { F } \\
=0.0000\end{array}$ & $\begin{array}{l}\text { Prob }>\text { F } \\
=0.0000\end{array}$ & $\begin{array}{l}\text { Prob }>\text { F } \\
=0.0000\end{array}$ & $\begin{array}{l}\text { Prob }>\text { F } \\
=0.0000\end{array}$ & $\begin{array}{l}\text { Prob }>F \\
=0.0000\end{array}$ \\
\hline Pesaran test & $\operatorname{Pr}=0.0000$ & $\operatorname{Pr}=0.0000$ & $\operatorname{Pr}=0.0000$ & $\operatorname{Pr}=0.0000$ & $\operatorname{Pr}=0.0000$ \\
\hline
\end{tabular}

Note: 1$\left.)^{*} p, 0.10,{ }^{* *} p, 0.05,{ }^{* * *} p, 0.01 .2\right) \mathrm{Z}$ value in parentheses.

Model (3) shows that, for the form of forward vertical specialization, the coefficient of it is positive at the level of $10 \%$, Hypothesis 3 is verified. The ratio of intermediate products exported to the third country is high, which means the country's industrial supporting facilities are gradually improved, furtherly, it can help Chinese MENs to integrate global advantageous resources through OFDI. In the meanwhile, model (4) indicates that, regard to GVC status, the coefficient of it is positive at the level of 5\%, Hypothesis 4 is proved. The high GVC status of host country's sub-industry is a significant factor for attracting China's OFDI.

Model (5) shows that, when considers both the influence of driven model and labor division of EU countries' GVC on China's OFDI location strategy, the coefficient of all core explanatory variables are positive at the level of $10 \%$ or above, which confirms the robustness of results of the model (1)-(4).

Besides that, from control variables perspective, as shown in regression (1)-(5), the coefficient of id is negative at the level of $10 \%$. To some extent, id is able to produce transaction costs such as information asymmetry, which obviously 
hinders China's OFDI location strategy, in the meanwhile, the coefficients of cost is negative at the level of $5 \%$ or above. In addition, except the coefficient of infra in model (1) is not significant, in models (2)-(5), the coefficient of this variable is positive at the level of $10 \%$ or above. Compared with producer driven model, high-level infrastructure environment plays an important role in the construction of global marketing network and information transmission between MENs. At the same time, the higher the level of vertical specialization and GVC status in the host country are, the better the infrastructure is, which attracts more China's OFDI. For the variable of open, from models (1) to (5), the coefficient of this variable is positive at the level of $5 \%$ or above.

\section{Conclusion and Management Implications}

Based on the GVC evolution of manufacturing industry in EU countries, this paper analyzes the impacts on location determinants of China's OFDI, brought about by host country's GVC driven mode and labor division at industry level. The empirical findings are as follows: first, from the perspective of GVC driven mode, producer driven mode depending high-tech level and human capital and buyer driven mode based on host country's market potential are important location factors for Chinese OFDI across EU member states. Secondly, from the perspective of GVC division of labor, the higher vertical specialization level and the higher GVC status of a manufacturing sub-industries in EU member states are the main factors attract China's OFDI inflow. Thirdly, the better infrastructure and higher foreign investment openness of EU countries promote China's OFDI location strategy, while the increase of bilateral institutional distance and labor cost will hinder China's OFDI location strategy.

Based on the result obtained above, this research puts forward the following three suggestions for Chinese MENs, aiming at assisting Chinese MNEs to better understand the comparative advantages of EU manufacturing industry and make reasonable OFDI strategies for improving their international competiveness. First, Chinese MNEs should further strengthen the cooperation with EU member states in high-technology and human capital driven industries as well as industries with high vertical specialization level and GVC status. Through strategic alliance, such as "Industry-university-research collaboration" or other mutually beneficial and win-win pattern, Chinese MENs can enhance their international competitiveness by benefiting from technology and knowledge spillover effects. Secondly, Chinese MENs lacking brand advantages can enter the EU countries through OFDI, which can improve their soft power, by improve their market share by joining local sales network and large market potential of the host country, and learning the advanced brand operation and management experience from partner enterprises. Last but not least, at country level, China should give full play to its "Country Specific Advantages" and further explore the potential of investment cooperation with EU countries, on the basis of China EU friendly economic and trade exchanges. 
However, there are some deficiencies in this paper. On the one hand, this paper uses the host country's technology level and human capital as producer driven mode's proxy variable, and the market potential is used as the agent variable of the buyer driven model, which are not microscopic enough and can not reflect the real level of manufacturing sub-industry in host country. And on the other hand, as WIOD only contains the basic data of 56 industrial sectors of 44 economies from 2000 to 2014, which makes China's OFDI in recent years unable to be observed. After new proxy variables are found and WIOD is updated, these two deficiencies can be furtherly overcome in the future.

\section{Acknowledgements}

We are grateful for the financial support from the general project of the National Social Science Foundation of China "Research on the prevention strategy of the vulnerability of the international competitiveness of Chin's advanced manufacturing enterprises under the global value double circle" (19BJY107).

\section{Conflicts of Interest}

The authors declare no conflicts of interest regarding the publication of this paper.

\section{References}

Balassa, B. (1976). Trade Liberalization among Industry Countries. New York: McGraw-Hill.

Chen, H., Liu, P., \& He, J. L. (2019). Openness and Governance Environment of European Countries and China's Direct Investment to Europe: An Analysis Based on Industry Panel Data of European Countries. International Economic and Trade Exploration, 2, 67-86.

Clegg, J., \& Voss, H. (2016). The New Two-Way Street of Chinese Direct Investment in the European Union. China-EU Law Journal, 5, 79-100. https://doi.org/10.1007/s12689-016-0063-x

Feenstra, R. C. (1998). Integration of Trade and Disintegration of Production in the Global Economy. Journal of Economic Perspectives, 4, 31-50. https://doi.org/10.1257/jep.12.4.31

Gao, Y. S., \& Zheng, Y. K. (2018). Research on the Level and Structure Difference of China EU Manufacturing Industry Integrating into Global Value Chain: From the Perspective of Vertical Specialization Division of Labor. French Research, 1, 1-16.

Gereffi, G., \& Korzeniewicz, M. (1994). Commodity Chains and Global Capitalism. Westport, CT: Praeger.

Henderson, J. (1998). Danger and Opportunity in the Asia-Pacific. In G. Thompson (Ed.), Economic Dynamism in the Asia Pacific (pp. 356-384). London: Routledge.

Huang, L. Y., Liu, D. D., \& Xie, H. Q. (2018). Research on the Harmonious Development of Outward Foreign Direct Investment and Inward Foreign Direct Investment. China Industrial Economics, 3, 80-97.

Ji, S. B., Li, S. H., \& Ma, S. J. (2018). Study of Multi-Dimensional Distances' Effects on China's OFDI in "the Belt and Road" Countries. World Economic Research, 1, 98-111.

Koopman, R., Powers, W., Wang, Z., \& Wei, S. J. (2010). Give Credit Where Credit Is 
Due: Tracing Value Added in Global Production Chains. Cambridge, MA: National Bureau of Economic Research. https://doi.org/10.3386/w16426

Li, F. (2015). The Status of International Division of Labor under Global Value Chain: An Analysis Based on Added Value. International Economics and Trade Research, 31, $31-42$.

Liu, H. Y., \& Mao, H. O. (2016). Effects of Manufacturing OFDI on Domestic Value-Added in Exports. China Industrial Economy, 7, 91-108.

Liu, Z. Q., \& Wang, Y. (2016). Economic Resource, Institutional Environment, and Location Choice: From Perspective of China's OFDI to EU. Economic Management, 2, 1-13.

Ma, S. Z., \& Liu, M. H. (2016). Research on the Third Country Effect of OFDI in China along the "One Belt and One Road": Based on Spatial Econometric Method. International Trade Issues, 7, 72-83.

Pei, C. H., \& Zheng, W. (2011). Country-Specific Advantages: Supplementary Explanation of International Investment Theory. Economic Research, 11, 21-35.

Wang, Z., Wei, S. J., \& Zhu, K. F. (2015). Gross Trade Accounting Method: Official Trade Statistics and Measurement of the Global Value Chain. China Social Sciences, 9, 108-127.

Zhu, J., \& Ren, R. M. (2018). Institutional Environment of Host Countries, Bilateral Investment Treaties and Location Choices of Cross-Border Acquisitions by Chinese Firms. World Economic Research, 3, 109-126. 